Two-Way Symmetrical Communication Pattern: Company Strategy to Build Engagement Through Social Media

Pola Komunikasi Simetris Dua Arah: Strategi Perusahaan Membangun Engagement Melalui Media Sosial

\title{
Two-Way Symmetrical Communication Pattern: Company Strategy to Build Engagement Through Social Media
}

\section{Pola Komunikasi Simetris Dua Arah: Strategi Perusahaan Membangun Engagement Melalui Media Sosial}

\author{
Chyntia Novy Girsang ${ }^{1}$, Dorien Kartikawangi ${ }^{2}$ \\ ${ }^{1}$ Program Pascasarjana, Departemen Ilmu Komunikasi, FISIP, Universitas Indonesia \\ Email: chyntia.novy@gmail.com \\ ${ }^{2}$ School of Communication, Atma Jaya Catholic Univesity of Indonesia* \\ Email: dorien.kartika@atmajaya.ac.id
}

Masuk tanggal : 09-03-2021, revisi tanggal : 11-11-2021, diterima untuk diterbitkan tanggal : 15-11-2021

\begin{abstract}
Engagaement in social media plays a significant role in stakeholders management. This study aims to describe the corporate communication strategy in building engagement through two-way symmetrical communication on Instagram social media content, as well as the engagement formed therein. This research uses a constructivist paradigm, qualitative approach with case study on Sinar Mas' Instagram. Primary data collection was done by in-depth interviews, while secondary data was obtained by observations on Sinar Mas' Instagram. The results show that corporate strategy to build engagement is by desaining relevant content to everyday life, using creative visual desain tailored to target audience, put audience in an equal position, create simple messages and insert questions so that it can further encourage two-way communication. Researchers also found that in building engagement, company effectively implement symmetrical communication by building interaction, dialogue, reciprocal communication, and trying to always respond the incoming messages. In this case, engagement that is formed is at the intermediate level or at the level of individual analysis which concluded from interaction results and cognitive, affective and behavior engagement of followers on Instagram.
\end{abstract}

Keywords: engagement, Instagram, social media, symmetrical communication

\begin{abstract}
Abstrak
Engagement melalui media sosial memainkan peran yang signifikan dalam pengelolaan pemangku kepentingan. Penelitian ini bertujuan untuk mendeskripsikan strategi komunikasi perusahaan dalam membangun engagement melalui pola komunikasi simetris dua arah pada konten media sosial Instagram, serta engagement yang terbentuk. Penelitian ini menggunakan paradigma konstruktivis, pendekatan kualitatif dengan studi kasus pada Instagram Sinar Mas. Pengumpulan data primer dilakukan dengan wawancara mendalam, sedangkan data sekunder diperoleh dari observasi terhadap Instagram Sinar Mas. Data dianalisis dengan menggunakan konsep komunikasi simetris dua arah dan tingkat keterlibatan. Hasil penelitian menunjukkan bahwa strategi perusahaan untuk membangun engagement adalah dengan merancang konten yang relevan dengan kehidupan sehari-hari, menggunakan visual desain kreatif yang disesuaikan dengan target khalayak, menempatkan khalayak dalam posisi yang setara, membuat pesan yang
\end{abstract}


sederhana dan menyisipkan pertanyaan sehingga dapat lebih mendorong komunikasi dua arah. Peneliti juga menemukan bahwa dalam membangun engagement, perusahaan menerapkan komunikasi simetris dengan membangun interaksi, dialog, komunikasi timbal balik, serta berusaha untuk selalu merespon pesan yang masuk. Dalam hal ini, engagement yang terbentuk berada pada tingkat menengah, yaitu pada tingkat analisis individu berdasarkan interaksi dan keterlibatan secara kognitif, afektif dan perilaku dari pengikut Instagramnya.

Kata Kunci: engagement, Instagram, komunikasi simetris, media sosial

\section{Pendahuluan}

Seiring perkembangan media sosial yang kian pesat, engagement (keterlibatan) menjadi perhatian penting bagi sejumlah perusahaan atau organisasi. Hal ini ditunjukkan dengan bagaimana perusahaan saat ini berupaya menciptakan pesan komunikasi yang dapat menarik perhatian dan keterlibatan dari khalayaknya di media sosial dengan menggunakan konten ataupun teks caption yang bersifat pertanyaan untuk memancing interaksi dengan publiknya di media sosial. Gaya berkomunikasi lama yang cenderung bersifat satu arah mulai ditinggalkan dan bergerak pada komunikasi dua arah untuk membangun engagement yang umumnya dilakukan melalui kontennya di media sosial. Pada tahun 2008, Richard Edelman, presiden dan CEO Edelman, sebuah agensi hubungan masyarakat independen terbesar di dunia, menyatakan bahwa keterlibatan publik adalah masa depan hubungan masyarakat. Dalam sebuah artikelnya, Forbes menekankan bahwa jika tujuan perusahaan adalah untuk membangun hubungan dengan khalayaknya, maka perusahaan tersebut harus melihat pada engagement (Forbes, 2017). Demikian juga dengan PR Indonesia yang menyatakan bahwa "content is the king, engagement is the queen", dimana hal ini berlaku bagi public relations, terutama ketika menjalankan perannya dalam menjalin komunikasi dan membangun engagement, khususnya melalui media sosial (Indonesia, 2019).

Keterlibatan terkait erat dengan bagaimana Public Relations (PR) memelihara para pemangku kepentingan, dan hal ini selalu terkait erat dengan dialog dan komunikasi dua arah dibandingkan dengan komunikasi satu arah (Yeomans \& Topic, 2015). Untuk dapat membangun keterlibatan dengan publik, maka PR perlu memahami publik mereka dan menemukan cara untuk melibatkan mereka. Melalui teknologi media sosial, ruang lingkup hubungan masyarakat telah berkembang untuk memasukkan lebih banyak peluang untuk berinteraksi langsung dengan para pemangku kepentingan di ruang yang sangat luas (Anderson, Swenson, \& Gilkerson, 2016). Keterlibatan pemangku kepentingan melalui media sosial adalah strategi komunikasi yang digunakan untuk mengembangkan dan memelihara hubungan dengan pemangku kepentingan yang dapat berkontribusi untuk mencapai tujuan organisasi (Carboni \& Maxwell, 2015).

Menyadari bahwa generasi millenials telah menjadi bagian dari khalayak terbanyak media sosial, dan juga dimana kini juga telah usia produktif dominan di Indonesia, mendorong perusahaan pada akhirnya menyesuaikan gaya dan pola 
Chyntia Novy Girsang, Dorien Kartikawangi:

Two-Way Symmetrical Communication Pattern: Company Strategy to Build Engagement Through Social Media

Pola Komunikasi Simetris Dua Arah: Strategi Perusahaan Membangun Engagement Melalui Media Sosial

komunikasinya untuk membangun keterlibatan (engagement) dengan khalayaknya. Salah satu karakteristik generasi millennial seperti yang dikemukakan oleh Sweeney (2012) adalah media/format agnostic yaitu dimana generasi millennial paling menikmati multimedia gerak penuh yang interaktif, gambar berwarna serta audio meskipun mereka dapat pula menggunakan berbagai media, bahkan teks sekalipun. Konsep komunikasi perusahaan yang dulunya cenderung kaku, dan bersifat satu arah kini telah mulai bertransformasi ke dalam bentuk konten dan pola komunikasi dua arah dan lebih bersifat horizontal, yang menempatkan perusahaan sejajar dengan khalayak di era millennial yang cenderung menyukai gaya komunikasi informal dan cair. Perusahaan tidak lagi hanya menyalin ulang bahasa komunikasi formal seperti teks rilis pers ke dalam format media sosial, namun telah menyesuaikan gaya dan pola berkomunikasi dengan khalayaknya di media sosial. Konten-konten yang sifatnya interaktif dan memancing khalayak untuk memberikan pendapat, komentar, ide-ide, bahkan preferensi mereka terhadap sesuatu telah menjadi pola komunikasi yang diaplikasikan korporasi saat ini. Berbeda dengan perusahaan rintisan atau startup company yang dapat dikatakan lebih adaptable dan lahir di dalam era perkembangan media baru, untuk perusahaan yang tergolong established company sendiri diperlukan upaya untuk menyesuaikan diri dengan era digital yang begitu cepat. Beberapa perusahaan yang termasuk dalam established company seringkali dilekatkan dengan stigma perusahaan yang kaku dan sulit beradaptasi dengan perkembangan zaman dan menyesuaikan diri dengan generasi yang ada. Namun melalui beberapa fenomena yang terjadi saat ini, dapat dilihat bahwa sejumlah established company telah mulai menyesuaikan diri dan mengimplementasikan pola komunikasi dua arah dengan publiknya di media sosial, salah satunya yaitu Sinar Mas.

Berdasarkan deskripsi di atas, penelusuran pada berbagai kajian dapat mendukung pemikiran tersebut. Sebagai payung ditetapkan relationship management theory yang berfokus dalam mengelola hubungan masyarakatorganisasi untuk menghasilkan manfaat bagi organisasi dan juga publik (Ledingham, 2003). Gagasan manajemen hubungan mewakili perubahan mendasar dalam fungsi dan arah hubungan masyarakat, pergerakan dari pengukuran dampak tradisional, seperti jumlah pesan komunikasi yang dihasilkan atau jumlah berita yang ditempatkan di media massa, menuju evaluasi terhadap inisiatif hubungan masyarakat berdasarkan dampaknya pada kualitas hubungan antara organisasi dan publik yang berinteraksi dengannya. Theaker (2016) mengemukakan bahwa kehumasan merupakan fungsi manajemen yang membantu membangun dan mengelola komunikasi, pemahaman, penerimaan dan kerjasama antara organisasi atau korporasi dengan publiknya. Hubungan masyarakat atau public relations juga dilihat sebagai kegiatan komunikasi yang membantu organisasi untuk melibatkan banyak publik (Taylor \& Kent, 2014)

Model simetris dua arah digambarkan sebagai model ideal hubungan masyarakat. Model ini menggambarkan tingkat kesetaraan komunikasi, dimana masing-masing pihak bersedia mengubah perilaku mereka untuk mengakomodasi kebutuhan pihak lain (Theaker, 2016). Model simetris dua arah lebih terdiri dari dialog daripada monolog (Grunig \& Hunt, 1984), yang menjadi tujuan dari model 
komunikasi simetris dua arah adalah untuk mendapatkan saling pengertian dan membangun dialog (Woodward, 2000) antara pihak-pihak yang didasarkan pada komunikasi dua arah dengan efek yang seimbang (Wilcox, Ault, Agee, \& Cameron, 1998). Hal yang sama berlaku untuk komunikasi simetris dua arah dalam konteks organisasi, dimana setiap orang harus diberi kesempatan yang sama dan dihormati sebagai manusia (Mersham, Rensburg, \& Skinner, 1995). Melalui penelitiannya, Grunig menunjukkan bahwa program komunikasi simetris lebih berhasil daripada komunikasi asimetris dalam membangun hubungan antara organisasi dan publik (Grunig, 2009).

Media sosial adalah platform alami yang digunakan untuk mendorong komunikasi dua arah antara organisasi dan pengguna media sosial (Lovejoy, Waters, \& Saxton, 2012; Saxton, Guo, \& Brown, 2007). Media sosial juga memberikan kesempatan untuk mengembangkan hubungan dengan khalayak melalui keterlibatan dan pesan utama (Roberts, 2016). Ditekankan pula bahwa media sosial telah mengubah cara organisasi membuat, mendistribusikan, dan menggunakan konten, serta bagaimana komunikator perusahaan mendefinisikan corporate images kepada jaringan online pemangku kepentingan atau stakeholders (Muntinga, Moorman, \& Smit, 2011). Konten sendiri merupakan salah satu fondasi dari sebuah bisnis. Konten mencakup semua informasi yang disediakan oleh produsen mengenai produk dan jasa yang dipasarkan, dapat berbentuk visual seperti infografis, video ataupun teks (Diamond, 2015). Konten digital yang disusun dan didistribusikan oleh perusahaan haruslah selaras dengan nilai-nilai yang dimiliki oleh perusahaan (Akbiyik, Andac, \& Karkar, 2016).

Dalam perspektif yang lain, Solis \& Breakenridge (2009) mengemukakan bahwa ketika berpartisipasi dan berkontribusi konten, saran, dan informasi, organisasi atau perusahaan membangun portofolio pengetahuan online yang meningkatkan reputasi, meningkatkan merek, dan meningkatkan profil perusahaan yang diwakili. Hal yang paling penting adalah partisipasi tersebut mendorong loyalitas pelanggan yang membawa perusahaan mendapatkan kepercayaan yang merupakan suatu hal yang berharga. Media sosial bersifat kolaboratif dan menekankan kapasitasnya bagi orang untuk berpartisipasi dan terhubung satu sama lain. Sifat kolaboratif dari media sosial menjadikannya lingkungan yang ideal untuk dialog (Page, 2011).

Keterlibatan dipandang sebagai pendekatan etis dan responsif secara sosial terhadap praktik komunikasi strategis, mendukung organisasi untuk memahami, merespons, dan pada akhirnya beradaptasi dengan pandangan dan harapan pemangku kepentingan dan masyarakat. Keterlibatan dengan pemangku kepentingan didefinisikan sebagai proses relasional dimana komunikasi, interaksi, koneksi, dan kolaborasi dicapai antara organisasi dan para pemangku kepentingannya untuk hasil keterlibatan dalam bentuk kognitif / afektif / perilaku (Johnston, 2018). Keterlibatan terkait erat dengan merawat para pemangku kepentingan yang berkomunikasi dengan praktisi PR, dan dengan cara ini keterlibatan selalu terkait erat dengan dialog dan komunikasi dua arah daripada bentuk komunikasi satu arah (Yeomans \& Topic, 2015). Kang (2014) mengoperasionalkan keterlibatan dengan menciptakan skala untuk mengukur tiga dimensinya: komitmen afektif (misalnya, ikatan emosional dengan suatu 
Chyntia Novy Girsang, Dorien Kartikawangi:

Two-Way Symmetrical Communication Pattern: Company Strategy to Build Engagement Through Social Media

Pola Komunikasi Simetris Dua Arah: Strategi Perusahaan Membangun Engagement Melalui Media Sosial

organisasi), efektivitas positif (misalnya, perhatian, minat, antusiasme), dan pemberdayaan (misalnya, self-efficacy dan kemampuan untuk berkolaborasi dan berdampak pada suatu organisasi). Pada tingkat individu, keterlibatan adalah keadaan psikologis yang terdiri dari dimensi kognitif, afektif, dan perilaku. Keterlibatan kognitif mewujudkan ide minat dan terlibat dalam suatu topik dan kemauan untuk memahami ide-ide kompleks, menguasai keterampilan yang sulit, dan menentukan apa yang dilihat dan dipahami. Keterlibatan afektif mencakup reaksi emosional positif dan negatif, seperti kenikmatan, ketakutan, kemarahan, dukungan, dan kepemilikan. Keterlibatan perilaku mewujudkan konsep interaksi, kolaborasi, tindakan, dan partisipasi (Johnston, 2018).

Pentingnya keterlibatan telah semakin ditingkatkan dengan pengembangan teknologi media digital, terutama media sosial, yang memberikan peluang yang tampaknya tak terbatas bagi publik untuk terlibat dengan organisasi, konten, dan satu sama lain (Jelen-Sanchez, 2017). Media sosial memberi organisasi peluang untuk terlibat dalam komunikasi dialogis yang simultan dengan banyak pemangku kepentingan di ruang publik (Carboni \& Maxwell, 2015). Penggunaan media sosial tidak hanya memfasilitasi komunikasi dua arah dengan pemangku kepentingan tetapi juga meningkatkan keterlibatan dan loyalitas pemangku kepentingan (Denktaş-Şakar \& Sürücü, 2020). Media sosial juga memfasilitasi keterlibatan dan dianggap sebagai alat untuk melibatkan khalayak dengan cara yang cepat dan hemat biaya (Wu, 2018). Dalam mempertimbangkan keterlibatan pemangku kepentingan, interaksi media sosial memainkan peran penting dalam membantu organisasi berkomunikasi dengan pemangku kepentingan mereka dan menerima umpan balik melalui berbagai reaksi khusus media sosial misalnya suka, berbagi, dan komentar (Manetti \& Bellucci, 2016). Keterlibatan juga digambarkan sebagai setiap kali pengunjung mengambil tindakan selain melihat atau membaca, seperti menyukai, berbagi, atau berkomentar (Paine, 2011). Keterlibatan online di media sosial dapat juga diklasifikasikan ke dalam tiga kategori: mengkonsumsi konten, misalnya menonton video; berkontribusi konten, misalnya terlibat dalam percakapan unggahan di dinding; dan membuat konten, misalnya menerbitkan dan berbagi video atau gambar pada halaman merek SNS (Muntinga et al., 2011).

Berdasarkan observasi dan riset pendahuluan yang dilakukan oleh peneliti, peneliti kemudian menetapkan salah satu established company di Indonesia, yaitu Sinar Mas sebagai objek dan studi kasus penelitian. Pemilihan objek dan studi kasus penelitian terhadap perusahaan Sinar Mas ini didasarkan pada pengamatan atau observasi yang dilakukan peneliti terhadap beberapa konten di media sosial Instagram Sinar Mas, dimana peneliti melihat bahwa telah terjadi perubahan gaya berkomunikasi yang sangat signifikan baik melalui konten dan pola komunikasi yang dilakukan oleh Sinar Mas di media sosial. Berangkat dari hal tersebut, permasalahan yang ingin diteliti melalui penelitian ini adalah bagaimana startegi perusahaan dalam membangun engagement melalui pola komunikasi dua arah, serta bagaimana engagement yang terbentuk di media sosialnya, yaitu Instagram Sinar Mas. Manfaat ilmiah dari penelitian ini adalah melengkapi penelitian sebelumnya dengan kebaruan analisis individual pada media sosial perusahaan. Sedangkan maanfaat praktis hasil penelitian yang merupakan evaluasi strategi 
komunikasi melalui media sosial, dapat digunakan oleh perusahaan untuk memperbaiki dan meningkatkan strategi komunikasinya.

\section{Metode Penelitian}

Penelitian ini menggunakan paradigma konstruktivis, dimana peneliti ingin mendapatkan pemahaman engagement yang terjadi antara perusahaan dengan khalayaknya. Penelitian menggunakan pendekatan kualitatif dengan sifat penelitian deskriptif, yang bertujuan menyajikan gambaran yang terperinci tentang situasi yang diteliti. Studi kasus ditetapkan sebagai metodeuntuk mengembangkan analisis mendalam tentang suatu fenomena atau kasus yang terjadi melalui satu perusahaan, yaitu Sinar Mas, dalam kurun waktu tertentu yakni 2019 - 2020. Dalam studi kasus ini, penelitian menggunakan single-case (embedded/multiple unit of analysis) desains, yaitu desain penelitian terhadap satu kasus dengan analisis multilevel. Studi kasus tunggal ditetapkan dengan pertimbangan bahwa Sinar Mas mepresentasikan fenomena komunikasi yang sedang terjadi secara umum.

Unit analisis dari penelitian ini adalah pada level organisasi, yaitu Sinar Mas. Peneliti memfokuskan penelitian pada media sosial Instagram yang digunakan perusahaan Sinar Mas selama periode 2019 - 2020. Teknik pengumpulan data primer menggunakan wawancara mendalam dengan informan yang kredibel. Informan pertama adalah Head of Social Media Sinar Mas. Informan kedua adalah Head of Corporate Communication Sinar Mas. Selain itu, ditetapkan tiga informan yang merupakan pengikut IG Sinar Mas yang paling aktif berinteraksi berdasarkan pada data pemantauan Sinar Mas "Top 10 Most Active Fans Instagram @sinar_masid berdasarkan Likes". Sedangkan data sekunder diperoleh dari internet dan Instagram Sinar Mas pada periode 2019 2020. Data diolah dengan menggunakan proses coding dan dianalisa berdasarkan konsep komunikasi simetris dua arah, dan tingkat engagement.

\section{Hasil Penemuan dan Diskusi}

\section{Strategi Komunikasi Perusahaan dalam Membangun Engagement Melalui Pola Komunikasi Simetris Dua Arah pada Konten Media Sosial Instagram}

Pemanfaatan media sosial Instagram oleh Sinar Mas digunakan untuk membangun, bahkan meningkatkan corporate reputation dan brand image Sinar Mas secara keseluruhan. Oleh Sinar Mas, media sosial juga digunakan untuk memfasilitasi interaksi dan percakapan. Media sosial dan konten adalah dua hal yang berkaitan erat. Muntinga et.al., (2011) juga menekankan dimana media sosial telah mengubah cara organisasi membuat, mendistribusikan, dan menggunakan konten, serta bagaimana komunikator perusahaan mendefinisikan corporate images kepada jaringan online pemangku kepentingan (stakeholders). Strategi komunikasi Sinar Mas melalui konten media sosial Instagram dikorelasikan dan disesuaikan dengan target khalayaknya, yang dalam hal ini adalah kelompok milennials dan professional. Dari data demografi Instagram @ sinar_masid diketahui bahwa mayoritas followers adalah berusia 24 - 35 tahun 
Chyntia Novy Girsang, Dorien Kartikawangi:

Two-Way Symmetrical Communication Pattern: Company Strategy to Build Engagement Through Social Media

Pola Komunikasi Simetris Dua Arah: Strategi Perusahaan Membangun Engagement Melalui Media Sosial

atau kategori generasi millenials, sehingga beberapa aspek seperti gaya bahasa, warna, jenis huruf, animasi harus disesuaikan, antara lain bahasa yang lebih informal, memperbanyak unsur visual daripada teks, menggunakan video yang lebih singkat, namun tetap dapat menarik perhatian, traffic, dan interaksi.

Berdasarkan temuan penelitian, diketahui bahwa pola komunikasi yang dibangun Sinar Mas dengan publiknya di media sosial banyak mengalami perubahan, dimana perusahaan telah menghindari bahasa-bahasa produk, mengubah visualisasi maupun bahasa di konten visual yang dulunya kaku dan tegas menjadi lebih santai dan informal, menjadi lebih humanis dan mengedepankan storytelling dibandingkan komunikasi satu arah. Sinar Mas juga melibatkan masyarakat yang menjadi penerima manfaat kegiatan sosial perusahaan, maupun karyawan untuk menjadi sosok yang bersuara di media sosial. Pola komunikasi juga dilakukan dengan semanusia mungkin, menempatkan khalayak setara dan seperti teman, dengan tujuan untuk membangun komunikasi dua arah atau timbal-balik. Perubahan pola komunikasi ini dinilai lebih efektif, berdampak, dan memiliki engagement yang lebih tinggi. Temuan ini sejalan dengan beberapa pemikiran yang mengatakan bahwa era baru hubungan masyarakat ditandai dengan adanya perubahan monolog menjadi dialog, fokus pada pengembangan kisah-kisah unik, yang memanusiakan dan mempersonalisasikan cerita khusus untuk berbagai kelompok yang ingin dijangkau, dan dimana perusahaan tidak lagi menggunakan bentuk komunikasi yang cenderung bersifat mengirimkan pesan kepada target khalayaknya (Solis \& Breakenridge, 2009). Salah satu temuan peneliti berkaitan dengan ini adalah dimana pada salah satu konten Sinar Mas yang memuat tentang kegiatan Corporate Social Resposibility perusahaan yaitu Bazaar Minyak Goreng.
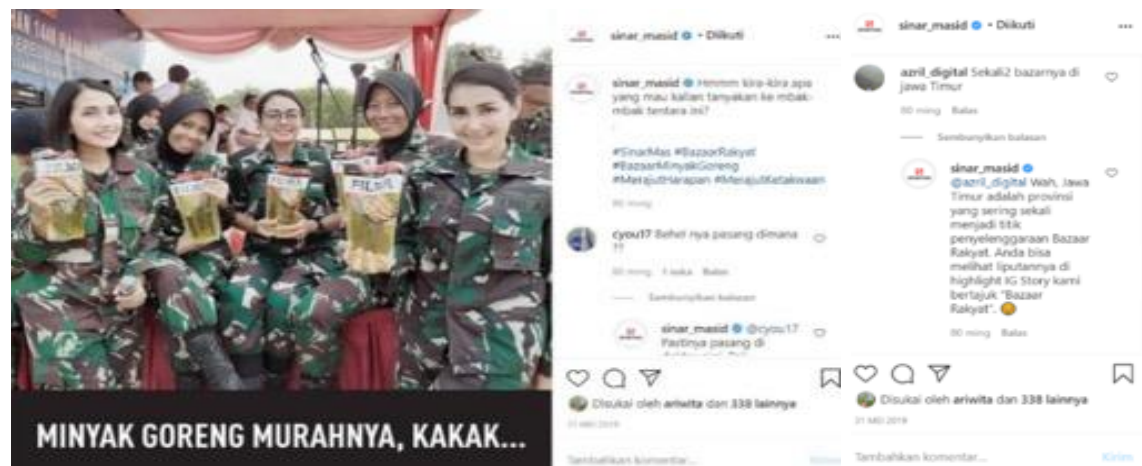

Gambar 1: Konten kegiatan CSR perusahaan yang dikemas dengan pola komunikasi dua arah (Sumber : Instagram @ sinar_masid)

Untuk membangun komunikasi dua arah, Sinar Mas selalu berupaya untuk merespon pesan dan komentar yang masuk di media sosial Instagramnya. Hal ini turut dipertegas oleh followers aktif Instagram @sinar_masid yang menyatakan bahwa pengelola media sosial (admin) selalu responsif dalam menanggapi pertanyaan dari pengikutnya. Temuan ini sejalan dengan observasi peneliti pada sebagian besar konten yang dipublikasikan Sinar Mas di Instagramnya. Beberapa temuan tersebut menunjukkan bahwa pola komunikasi yang dilakukan Sinar Mas 
selaras dengan konsep komunikasi simetris dua arah dalam konteks organisasi, dimana setiap orang harus diberi kesempatan yang sama dan dihormati sebagai manusia (Mersham et al., 1995). Namun sebagaimana dijelaskan juga oleh Theaker (2016) dimana model simetris dua arah melibatkan ide-ide dialog yang memungkinkan perusahaan dan publiknya bertukar pandangan yang memungkinkan keduanya untuk saling mempengaruhi dan menyesuaikan sikap dan perilaku, peneliti belum menemukan bentuk interaksi ataupun dialog pada ranah tersebut di Instagram @sinar_masid. Ide-ide dialog yang terbentuk di sebagian besar konten Instagram @ sinar_masid, menurut analisa peneliti, sifatnya adalah terbatas pada mengumpulkan pandangan dan masukan dari pengikutnya dalam rangka membangun dan meningkatkan engagement. Meski tidak secara khusus terdapat dialog di Instagram @sinar_masid yang bertujuan untuk saling menyesuaikan sikap dan perilaku, atau bahkan untuk mengelola konflik (Grunig, 2009), peneliti memandang bahwa keterlibatan dan dialog yang terbentuk dengan khalayak memberikan pendapat, masukan atau komentar dapat menjadi pertimbangan dan mempengaruhi langkah strategis yang mungkin akan diambil oleh perusahaan. Sebagai contoh, ditunjukkan melalui salah satu konten Throwback Thursday berikut.

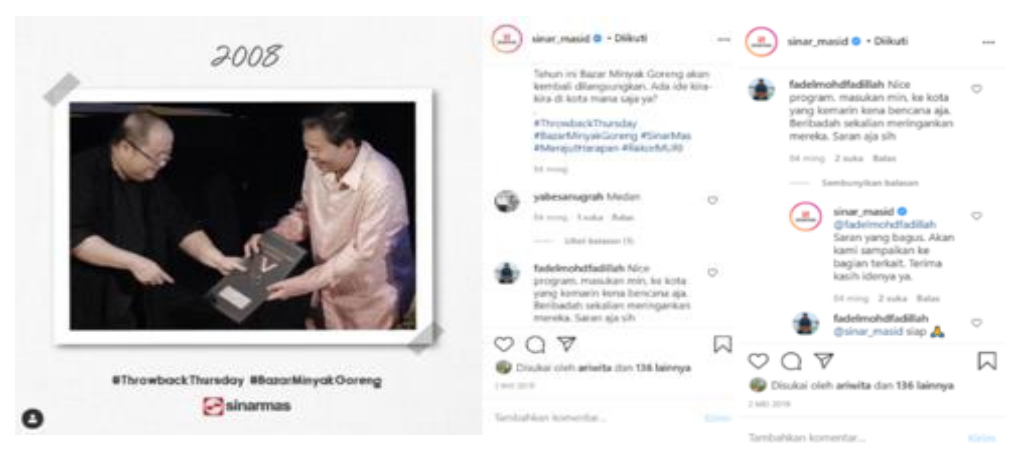

Gambar 2: Masukan yang diperoleh oleh perusahaan dengan memanfaatkan dialog dan komunikasi dua arah (Sumber : Instagram @ sinar_masid)

Dari temuan penelitian, peneliti juga mengidentifikasi dan menganalisis jenis-jenis konten yang dapat menciptakan engagement dengan followers di media sosial Instagram @sinar_masid sebagai berikut :

1. Konten yang bersifat parodi atau humor

2. Konten yang memiliki kedekatan dengan kehidupan personal khalayak

3. Konten dalam bentuk kuis atau trivia

4. Konten interaktif yang sifatnya pertanyaan, pilihan dan pendapat

5. Konten yang sifatnya riding the wave atau sedang menjadi topik perbincangan (trending topic) 
Chyntia Novy Girsang, Dorien Kartikawangi:

Two-Way Symmetrical Communication Pattern: Company Strategy to Build Engagement Through Social Media

Pola Komunikasi Simetris Dua Arah: Strategi Perusahaan Membangun Engagement Melalui Media Sosial
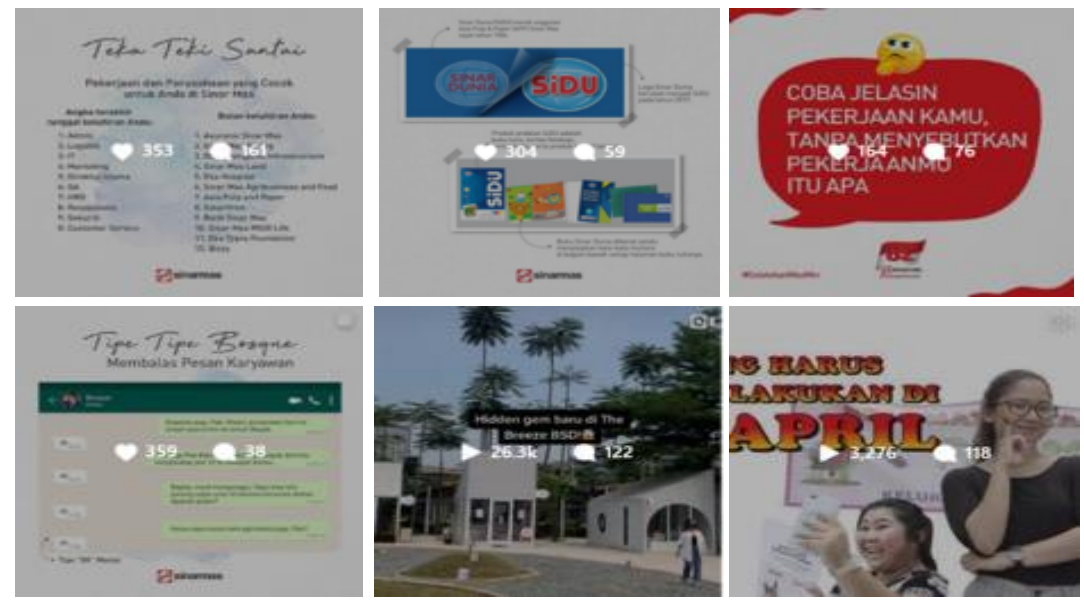

Gambar 3: Jenis Konten yang Banyak Menarik Engagement

(Sumber : Instagram @sinar_masid)

Dari hasil wawancara dan observasi penelitian secara keseluruhan, peneliti merumuskan strategi komunikasi perusahaan dalam membangun engagement sebagai berikut:

Tabel 1. Formulasi strategi komunikasi Sinar Mas dalam membangun engagement melalui pola komunikasi simetris dua arah

\begin{tabular}{|c|c|}
\hline Aspek Strategi & Action \\
\hline Target khalayak & $\begin{array}{l}\text { Menetapkan target khalayak yaitu karyawan dan masyarakat } \\
\text { umum dengan rentang usia } 24-35 \text { tahun }\end{array}$ \\
\hline Konten & $\begin{array}{l}\text { 1. Merancang pillar content atau tema-tema konten untuk } \\
\text { mendorong engagement } \\
\text { 2. Mengangkat konten-konten yang berhubungan erat dan } \\
\text { relevan dengan kehidupan sehari-hari } \\
\text { 3. Merancang konten-konten yang bersifat pilihan } \\
\text { pertanyaan, dengan bahasa sehari-hari dan ringan }\end{array}$ \\
\hline Teks atau Caption & $\begin{array}{l}\text { 1. Singkat, sederhana, gaya bahasa lebih informal } \\
\text { 2. Membuat caption yang sifatnya pertanyaan untuk } \\
\text { memancing pendapat dan komentar }\end{array}$ \\
\hline Visualisasi & $\begin{array}{l}\text { Membuat desain, warna, font, animasi, maupun video yang } \\
\text { lebih menarik, sesuai dengan target khalayak. }\end{array}$ \\
\hline Distribusi & $\begin{array}{l}\text { Tidak melakukan mirroring, menentukan platform yang tepat, } \\
\text { konten-konten yang ditujukan untuk khalayak dengan kategori } \\
\text { usia muda, menggunakan media sosial Instagram. }\end{array}$ \\
\hline Frekuensi & $\begin{array}{l}\text { Dibatasi pada 3-4 konten dalam } 1 \text { minggu untuk di linimasa } \\
\text { (feed). Publikasi konten di Instagram Story dilakukan ketika } \\
\text { tidak melakukan posting di linimasa ( feed) Instagram. }\end{array}$ \\
\hline Waktu & $\begin{array}{l}\text { Menetapkan jam posting dengan mempertimbangkan } \\
\text { kebiasaan khalayak dalam mengakses media sosial, secara } \\
\text { garis besar: } \\
\text { 1. Pukul 1-2 siang (setelah jam makan siang) } \\
\text { 2. Pukul } 5 \text { sore }-7 \text { malam (prime time) } \\
\text { 3. Pukul } 7 \text { - } 8 \text { pagi saat hari-hari besar tertentu }\end{array}$ \\
\hline Dialog/Percakapan & Berupaya merespon setiap pertanyaan dan komentar yang ada \\
\hline
\end{tabular}




\begin{tabular}{|c|c|}
\hline & secara dua arah dan menempatkan khalayak seperti teman \\
\hline Likes & $\begin{array}{l}\text { Menciptakan lebih banyak konten yang bersifat riding the } \\
\text { wave, parodi, dan menghibur }\end{array}$ \\
\hline Comment & $\begin{array}{l}\text { Menggali interaksi dengan membuat konten yang modelnya } \\
\text { pertanyaan, menggunakan bahasa yang mengundang rasa } \\
\text { ingin tahu, maupun melalui program kuis }\end{array}$ \\
\hline Share & $\begin{array}{l}\text { Mengemas konten semenarik mungkin, dalam bentuk } \\
\text { infografis singkat, padat, dan jelas agar lebih mudah dipahami } \\
\text { ketika konten tersebut dibagikan kembali }\end{array}$ \\
\hline
\end{tabular}

\section{Engagement yang Terbentuk antara Perusahaan dan Publiknya di Media Sosial Melalui Pola Komunikasi Simetris Dua Arah}

Sinar Mas memandang engagement sebagai sesuatu yang penting dan sangat diperlukan di era sekarang. Dengan membangun engagement, Sinar Mas dapat mendorong kepercayaan dan rasa loyal dari followers terhadap Sinar Mas. Followers yang loyal dapat menjadi teman dan partner yang membantu perusahaan meredam sentimen-sentimen negatif di media sosial. Seperti yang dikemukakan oleh Solis \& Breakenridge (2009) bahwa ketika berpartisipasi dan berkontribusi konten, saran, dan informasi, perusahaan membangun portofolio pengetahuan online yang meningkatkan reputasi, merek, dan profil perusahaan yang diwakili. Hal yang paling penting adalah partisipasi tersebut mendorong loyalitas pelanggan yang membawa perusahaan mendapatkan kepercayaan yang merupakan suatu hal yang berharga.

Engagement melalui media sosial menjadi salah satu perhatian Sinar Mas. Berdasarkan wawancara diketahu bahwa salah satu Objectives and Key Result perusahaan adalah rata-rata interaksi (engagement rate) dengan angka minimal 3\%. Dalam mempertimbangkan keterlibatan pemangku kepentingan, interaksi media sosial memainkan peran penting dalam membantu organisasi berkomunikasi dengan pemangku kepentingan mereka dan menerima umpan balik melalui berbagai reaksi khusus media sosial misalnya suka, berbagi, dan komentar (Manetti \& Bellucci, 2016). Engagement juga digambarkan dengan setiap kali pengunjung mengambil tindakan seperti menyukai, berbagi, atau berkomentar (Paine, 2011). Dari hasil wawancara diketahui bahwa indikator keterlibatan (engagement) di media sosial Instagram Sinar Mas terdiri atas beberapa metriks seperti likes, comment, share, save, dan reach yang mencapai lebih dari $10 \%$ dari jumlah followers.

Untuk menganalisis engagement yang terbentuk di media sosial Instagram @ sinar_masid, sebagaimana diketahui bahwa keterlibatan menurut Johnston (2018) adalah keadaan psikologis yang terdiri dari dimensi kognitif, afektif, dan perilaku. Keterlibatan kognitif adalah terlibat dalam suatu topik dan kemauan untuk memahami ide-ide kompleks. Keterlibatan afektif mencakup reaksi emosional positif dan negatif. Sementara keterlibatan perilaku ditunjukkan melalui interaksi, kolaborasi, tindakan, dan partisipasi. Berdasarkan hasil wawancara dengan narasumber, peneliti menemukan bahwa :

\section{a. Keterlibatan Kognitif}

Informan 1 menjelaskan bahwa keterlibatan kognitif terjadi lewat minat, perhatian, atau antusiasme khalayak Sinar Mas yang berkaitan dengan 
Chyntia Novy Girsang, Dorien Kartikawangi:

Two-Way Symmetrical Communication Pattern: Company Strategy to Build Engagement Through Social Media

Pola Komunikasi Simetris Dua Arah: Strategi Perusahaan Membangun Engagement Melalui Media Sosial

keingintahuan pada bagaimana cara bergabung dengan perusahaan, serta pengetahuan baru dan pemahaman mereka terhadap produk-produk Sinar Mas yang tanpa sadar telah banyak digunakan dalam kehidupan sehari-hari. Hal ini sejalan dengan penjelasan ketiga informan yang merupakan followers aktif @ sinar_masid, dimana konten dapat memenuhi kebutuhan informasi tentang Sinar Mas karena selalu menyajikan informasi terkini, tentang perusahaan maupun implementasi nilai perusahaan melalui produk usahanya, yang dikemas secara singkat, padat, jelas dan menarik sehingga mudah dipahami. Konten juga sesuai dengan minat atau perhatian. Sehingga dalam hal ini, keterlibatan kognitif dapat diketahui dari bagaimana karyawan ingin mengetahui perkembangan perusahaan, serta mendapatkan bahan edukasi untuk memperkenalkan produkproduk Sinar Mas melalui konten Instagram, juga bagaimana followers mendapatkan pengetahuan tentang produk Sinar Mas yang tidak banyak diketahui sebelumnya.

\section{b. Keterlibatan Afektif}

Keterlibatan afektif ditunjukkan melalui ikatan emosional yang terbentuk. Menurut Informan 1, hal ini dapat terlihat dari bagaimana khalayak sering memberikan comment dan likes atas konten-konten yang dipublikasikan, ikut membela perusahaan dalam menanggapi komentar negatif di media sosial, serta rasa bangga sebagai karyawan yang pernah menjadi bagian dari Sinar Mas. Dari sudut pandang followers aktif @sinar_masid, ikatan emosional yang terbentuk dapat terlihat dari bagaimana followers memiliki rasa kedekatan emosional dari konten yang disajikan karena berhubungan dengan kehidupan sehari-hari, terutama yang mendukung pekerjaan. Namun berdasarkan hasil observasi pada sejumlah komentar di Instagram @sinar_masid, peneliti menemukan bahwa khalayak secara aktif memberikan dukungan terhadap sejumlah langkah dan kegiatan positif perusahaan, misalnya pada kegiatan CSR, bantuan, donasi, maupun pada peringatan ulang tahun perusahaan. Bentuk dukungan tersebut menurut peneliti juga merupakan salah satu bentuk keterlibatan afektif.

\section{c. Keterlibatan Perilaku}

Informan pertama mengemukakan bahwa keterlibatan perilaku dapat diketahui melalui kolaborasi dengan publik yang dilakukan lewat kegiatan yang dapat melibatkan masyarakat luas, misalnya melalui kompetisi atau lomba. Keterlibatan perilaku tersebut ditunjukkan dengan partisipasi publik terhadap kampanyekampanye yang dilakukan, dan interaksi mereka di media sosial Sinar Mas. Sedangkan dari sisi followers aktif @sinar_masid, mengatakan bahwa konten yang disajikan di Instagram Sinar Mas menarik dan informatif sehingga mereka memiliki dorongan untuk memberikan likes, comment, dan share. Lebih jauh dari itu, peneliti melihat bahwa keterlibatan perilaku dapat melampaui sejumlah indikator engagement di media sosial seperti likes, comment, dan share. Berdasarkan observasi peneliti melalui Instagram @sinar_masid, melalui media sosialnya, Sinar Mas secara berkelanjutan terus berupaya mengajak keluarga besar Sinar Mas melalui penggalangan donasi bagi karyawan Sinar Mas yang terdampak pandemi COVID-19 seperti buruh pabrik, office boy, security, dan lain-lain. Peneliti menemukan partisipasi dan tindakan sejumlah karyawan terhadap kegiatan donasi tersebut. Hal ini menunjukkan bahwa keterlibatan 
perilaku tidak hanya terbatas partisipasi terhadap kegiatan kompetisi namun juga aksi sosial perusahaan yang dikampanyekan melalui media sosial.

Dalam (Johnston \& Taylor, 2018), terdapat tiga tingkatan pengukuran keterlibatan yang potensial, meliputi manifestasi tingkat rendah, pemahaman dan koneksi tingkat menengah, dan tindakan dan dampak pada tingkat yang lebih tinggi.

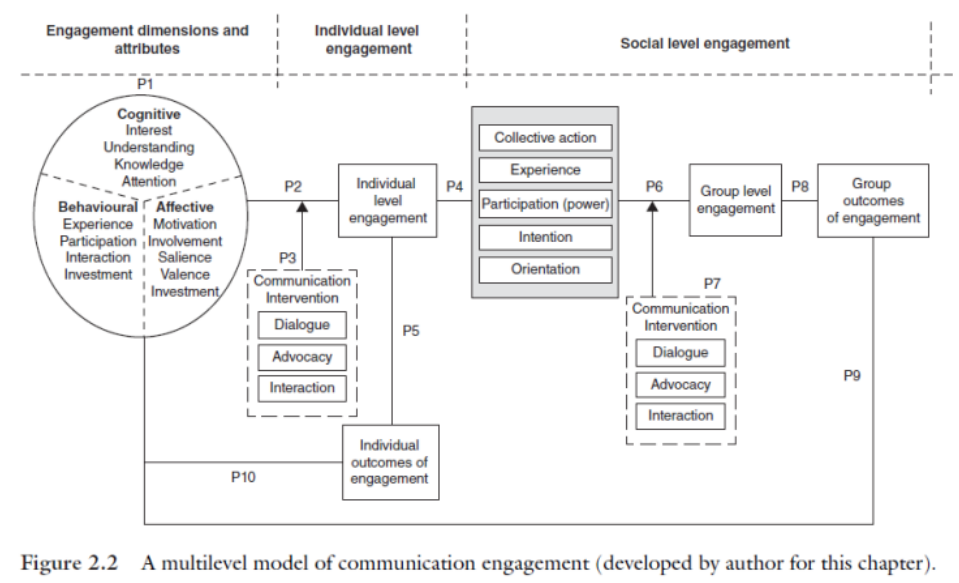

Gambar 4. Model Keterlibatan Bertingkat (Sumber : Johnston, 2018)

Tingkat pertama adalah tingkat keterlibatan terendah dan pengukuran akan menunjukkan adanya aktivitas, meliputi penghitungan dan jumlah tayangan media sosial seperti page likes dan visit, serta pemantauan media tradisional dan media sosial. Tingkat kedua adalah tingkat keterlibatan menengah. Pengukuran akan menunjukkan koneksi dan hubungan tetapi pada tingkat analisis individu, misalnya tingkat kepercayaan, legitimasi, dan kepuasan. Sementara kualitas interaksi dapat diukur dengan hasil dari interaksi seperti hasil kognitif/afektif konsumen jangka panjang atau hasil perilaku. Sedangkan tingkat ketiga adalah tingkat keterlibatan tertinggi dengan pengukuran yang berfokus pada tindakan dan dampak pada tingkat analisis sosial, yang dapat mencakup indikator sipil, partisipasi kelompok atau indikator perubahan sosial, serta tindakan sebagai hasil dari keterlibatan (Johnston \& Taylor, 2018).

Berdasarkan analisis terhadap hasil wawancara maupun observasi, peneliti menemukan bahwa keterlibatan yang terbentuk melalui media sosial Instagram @ sinar_masid berada pada tingkat kedua atau tingkat keterlibatan menengah. Koneksi dan hubungan terjadi tetapi pada tingkat analisis individu. Hal ini dapat disimpulkan dari kualitas dan hasil interaksi baik secara kognitif, afektif, dan perilaku dari pengikutnya sebagaimana yang diketahui dari hasil wawancara ketiga followers aktif Instagram @sinar_masid. Meski belum pada tahap keterlibatan tinggi, keterlibatan pengguna dengan komunikasi media sosial organisasi menandakan bahwa organisasi telah mengupayakan untuk memenangkan persaingan dalam mendapatkan perhatian pengguna. Sejalan dengan yang dikemukakan oleh Carboni \& Maxwell (2015), ketika pemangku 
Chyntia Novy Girsang, Dorien Kartikawangi:

Two-Way Symmetrical Communication Pattern: Company Strategy to Build Engagement Through Social Media

Pola Komunikasi Simetris Dua Arah: Strategi Perusahaan Membangun Engagement Melalui Media Sosial

kepentingan terlibat dalam platform media sosial, mereka akan lebih mungkin untuk terlibat dengan organisasi dengan cara yang lain.

Melihat betapa pentingnya membangun engagement seperti yang dikemukakan oleh Informan pertama dan kedua, namun dari temuan penelitian diketahui pula bahwa engagement melalui media sosial tidak menjadi satusatunya faktor yang mempengaruhi strategi komunikasi perusahaan secara keseluruhan. Engagement di media sosial hanya salah satu komponen yang dilihat dalam hal employer branding dan corporate reputation. Karena engagement di media sosial belum tentu membawa sentimen positif terhadap perusahaan. Engagement dari segi offline juga dibutuhkan untuk memperkuat engagement yang terbentuk di media sosial. Dalam hal ini, perusahaan melihat tetap perlunya membangun engagement dengan sejumlah pemangku kepentingan melalui berbagai kegiatan offline.

Pada akhirnya, melalui hasil dan analisis penelitian, peneliti menemukan bahwa konten dan engagement memiliki relevansi satu sama lain. Hal ini terjadi melalui pola komunikasi simetris dua arah yang diterapkan perusahaan dengan menciptakan lingkungan media sosial yang mendukung kesetaraan komunikasi, dialog, dan komunikasi timbal balik antara perusahaan melalui konten Instagramnya dengan khalayak di media sosial Instagram perusahaan tersebut. Selain itu, dorongan untuk terlibat (engage) dengan perusahaan melalui konten Instagramnya didukung oleh pengemasan konten yang menarik, informatif, dan memiliki relevansi atau kedekatan dengan kehidupan sehari-hari dari target khalayaknya.

\section{Simpulan}

Strategi perusahaan untuk membangun engagement melalui media sosial dilakukan dengan merancang konten yang dekat dengan kehidupan sehari-hari, menggunakan visual desain kreatif yang disesuaikan dengan target khalayak (generasi millenials) serta menempatkan khalayak dalam posisi yang sejajar (horizontal) sebagai teman sehingga dapat lebih mendorong komunikasi dua arah, serta membuat pesan yang sederhana dan memancing pertanyaan. Engagement melalui media sosial dilihat dari beberapa aspek seperti likes, comment, dan share. Aspek comment di media sosial Instagram @sinar_masid menjadi salah satu perhatian khusus peneliti, karena interaksi ini dapat menunjukkan kesetaraan komunikasi, dialog, komunikasi timbal-balik yang menjadi fokus dalam konsep pola komunikasi simetris dua arah. Peneliti menemukan bahwa Sinar Mas telah secara efektif menerapkan pola komunikasi ini dengan berupaya membangun dialog dan komunikasi timbal-balik, berusaha untuk selalu merespon pertanyaan/komentar yang ada, berkomunikasi semanusia mungkin dengan menempatkan khalayaknya sebagai teman.

Engagement yang terbentuk berada pada tingkat menengah atau pada tingkat analisis individu yang dapat disimpulkan dari kualitas dan hasil interaksi baik secara kognitif, afektif, dan perilaku dari pengikutnya di media sosial Instagram. Meski engagement merupakan sesuatu yang penting bagi perusahaan, namun engagement di media sosial tidak menjadi satu-satunya faktor yang 
mempengaruhi strategi komunikasi perusahaan secara keseluruhan. Engagement secara offline tetap dibutuhkan untuk memperkuat engagement yang terbentuk di media sosial.

Peneliti menyarankan penelitian selanjutnya terhadap engagement di media offline dapat memperkaya temuan penelitian ini. Pendekatan kuantitatif melalui metode survei disarankan pada penelitian selanjutnya untuk mengetahui faktor-faktor yang mendorong engagement khalayak di media sosial dengan perusahaan atau organisasi. Pada penelitian ini, peneliti menggunakan landasan Relationship Management Theory yang menekankan pada aktivitas komunikasi yang menghubungkan perusahaan/organisasi dengan publiknya. Penelitian selanjutnya dapat menggunakan landasan teori lain dalam public relations, seperti Teori Dialogis Public Relations (Dialogic Public Relations Theory) yang secara fokus menempatkan keterlibatan dalam dialog dan memberikan langkah-langkah tentang bagaimana organisasi dan publik dapat memberlakukan keterlibatan. Sedangkan sebagai saran praktis, perusahaan dapat memanfaatkan hasil penelitian evaluatif ini untuk mengembangkan strateginya agar menacapai tingkat engagement yang tinggi.

\section{Daftar Pustaka}

Akbiyik, F., Andac, A., \& Karkar, A. (2016). Customer Satisfaction Factor in Digital Content Marketing : Isparta Province as an Example. International Journal of Social Science Studies, 4(5). https://doi.org/10.11114/ijsss.v4i5.1471

Anderson, B. D., Swenson, R., \& Gilkerson, N. D. (2016). Understanding Dialogue and Engagement Through Communication Experts' Use of Interactive Writing to Build Relationships. International Journal of Communication, 10, 4095-4118.

Carboni, J. L., \& Maxwell, S. P. (2015). Effective Social Media Engagement for Nonprofits : What Matters? Journal of Public and Nonprofit Affairs, 1(1), $18-28$.

Denktaş-Şakar, G., \& Sürücü, E. (2020). Stakeholder engagement via social media: an analysis of third-party logistics companies. The Service Industries Journal, 40(11-12), 866-889. https://doi.org/10.1080/02642069.2018.1561874

Diamond, S. (2015). The Visual Marketing Revolution. Jakarta: PT Serambi Ilmu Semesta.

Forbes. (2017). How To Sell The Importance Of Engagement Over Fan Growth On Social Media. from https://www.forbes.com/sites/joeescobedo/2017/06/12/social-mediaengagement/\#6ed98b612193

Grunig, J. E. (2009). Paradigms of global public relations in an age of digitalization. PRism, 6 (2), 1-19.

Grunig, J. E., \& Hunt, T. (1984). Managing Public Relations. New York: CBS College Publishing. 
Chyntia Novy Girsang, Dorien Kartikawangi:

Two-Way Symmetrical Communication Pattern: Company Strategy to Build Engagement Through Social Media

Pola Komunikasi Simetris Dua Arah: Strategi Perusahaan Membangun Engagement Melalui Media Sosial

Indonesia, P. (2019). Membangun "Engagement" Melalui Media Sosial. Retrieved from https://www.prindonesia.co/detail/1418/MembangunEngagement-Melalui-Media-Sosial

Jelen-Sanchez, A. (2017). Engagement in public relations discipline: Themes, theoretical perspectives and methodological approaches. Public Relations Review. Retrieved from http://dx.doi.org/10.1016/j.pubrev.2017.04.002

Johnston, K. A. (2018). Engagement. The International Encyclopedia of Strategic Communication, 1-10.

Johnston, K. A., \& Taylor, M. (2018). The Handbook of Communication Engagement (First Edit). John Wiley \& Sons, Inc. Retrieved from https://ebookcentral.proquest.com

Kang, M. (2014). Understanding public engagement: Conceptualizing and measuring its influence on supportive behavioral intentions. Journal of Public Relations Research, 26(5), 399-416. Retrieved from doi:10.1080/1062726X.2014.956107

Ledingham, J. A. (2003). Explicating Relationship Management as a General Theory of Public Relations. Journal of Public Relations Research, 15(2), 181-198. https://doi.org/10.1207/S1532754XJPRR1502

Lovejoy, K., Waters, R. D., \& Saxton, G. D. (2012). Information, community, and action: How nonprofit organizations use social media. Journal of Computer Mediated Communication, 17, 337-353.

Manetti, G., \& Bellucci, M. (2016). The use of social media for engaging stakeholders in sustainability reporting. Accounting, Auditing \& Accountability Journal, 29(6), 985-1011.

Mersham, G. M., Rensburg, R. S., \& Skinner, J. C. (1995). Public Relations, Development and Social Investment: A Southern African Perspective. Pretoria: Van Schaik.

Muntinga, D. G., Moorman, M., \& Smit, E. G. (2011). Introducing COBRAs: Exploring motivations for brand-related social media use. International Journal of Advertising, 30(1), 13-46.

Page, R. (2011). Stories and Social Media : Identities and Interaction. Routledge. Retrieved from http://ebookcentral.proquest.com/lib/indonesiauebooks/detail.action?docID $=958478$

Paine, K. (2011). Measure what matters: Online tools for understanding customers, social media, engagement, and key relationships. Westford, MA: John Wiley \& Sons.

Roberts, J. (2016). Writing for Strategic Communication Industries. Ohio: The Ohio State University.

Saxton, G., Guo, C., \& Brown, W. (2007). New dimensions of nonprofit effectiveness: The application and promise of internet based technologies. Public Performance and Management Review, 31, 144-171.

Solis, B., \& Breakenridge, D. (2009). Praise for Putting the Public Back in Public Relations. New Jersey: Pearson Education, Inc.

Sweeney, B. R. (2012). Millennial Behaviors \& Demographics, 1-10. 
Taylor, M., \& Kent, M. L. (2014). Dialogic Engagement: Clarifying Foundational Concepts. Journal of Public Relations Research, 26(5), 384-398. https://doi.org/10.1080/1062726X.2014.956106

Theaker, A. (2016). The Public Relations Handbook (5th Editio). New York: Routledge.

Wilcox, D. L., Ault, P. H., Agee, W. K., \& Cameron, G. T. (1998). Public Relations: Strategies and Tactics. New York: Longman.

Woodward, W. D. (2000). Transactional Philosophy as a Basis for Dialogue in Public Relations. Journal of Public Relations Research, 12(3), 255-275.

Wu, Y. (2018). Social media engagement in the digital age. Newspaper Research Journal, 39(3), 287-296. https://doi.org/10.1177/0739532918796236

Yeomans, L., \& Topic, M. (2015). Engagement and Empathy Discourses in Corporate Communication: The Case of "The Science of Engagement." Romanian Journal Of Communication And Public Relations, 17(3), 27-39. 